\title{
M. Butterfly Filminin Yapı Sökümcü Analizi
}

\author{
Zühre Canay Güven* \\ Meral Serarslan**
}

\section{Özet}

Sinemada kadınlık ve erkeklik temsillerinin egemen söylemi ataerkil yapıyı devam ettiren bir biçimde olduğu ifade edilebilir. Yalnızca kadınlık ve erkeklik biçimleri değil, sinemadaki egemen söylemin bir diğer boyutu da Doğu/Batı toplumlarına yöneliktir. Bu söylemde Doğu eğitilmesi gereken bir toplum olarak tasvir edilirken, Batı güçlü ve iktidar sahibi olarak tasvir edilmektedir. Yine sinemanın egemen söyleminde karşımıza Doğu'nun kadınlık ve Batı'nın erkeklik hali ile ilişkilendirilmesi çıkmaktadır. M. Butterfly filmi ise bu hiyerarşik söylemi biçimsel olarak yıkıma uğratmaktadır. Bu araştırmada $M$. Butterfly filmi kadın/erkek, Doğulu/Batılı olma biçimlerini ters yüz etmesi iktidar/kimlik nedir sorusu üzerinden incelenmektedir. Bu araştırma anlamın ikircikliğinden yola çıklarak, bir taraftan Batı'nın Doğu üzerindeki hegemonyasını sorgulamayı amaçlarken, diğer yandan karşı-hegemonya biçimlerini tartışmaktadır. Bunun yanı sıra M. Butterfly eserinin konu olarak dayandı̆̆ı Madam Butterfly opera eserindeki kahraman ile incelenen eserdeki kahramanın intihar etmesi üzerinden kimlik ve cinsiyet rollerinin süreklilikleri, ikilemleri ve çıkmazları ortaya konulmuştur. Bu çalışma niteliksel olup, metinin analizinde yapısökümcü çözümlemeden yararlanılmıştır. Araştırmanın sonucunda, filmde herhangi bir yapının nihai olarak inşa edilmediği, kurulan yapıların sürekli el değiştirdiği bulunmuştur.

Anahtar Kelimeler: Oryantalizm, Film Çalışmaları, Toplumsal Cinsiyet, Temsil, M. Butterfly.

ORCID ID : *: https://orcid.org/0000-0002-3715-2089, **: https:// orcid.org/0000-0003-2059-5585

E-mail : *: canayguven@hotmail.com, **: mserarslan@selcuk.edu.tr

DOI: 10.31122/ sinefilozofi.358193

Geliş Tarihi - Recieved: 27.11.2017

Kabul Tarihi - Accepted: 09.06.2018 


\title{
The Deconstruction Analyses of M. Butterfly
}

\author{
Zühre Canay Güven* \\ Meral Serarslan*
}

\begin{abstract}
It can be claimed that the representations of femininity and masculinity in the cinema reinforce the dominant masculine discourse. Not only representations of femininity and masculinity, but also another dimension of the sovereign discourse about Eastern/Western societies in mainstream cinema. While East is depicted as powerful hegemonic, East is represented as a place that needs to be civilized. Furthermore, East is associated with femininity and the West with masculinity in the dominant discourse of the cinema. The film, M. Butterfly, reverses this hierarchical discourse formally. M. Butterfly was examined through the question of what power/identity is through taking into consideration of this reversed discourse of East/West and feminity/masculinity. The ambiguity of meaning was emphasized while questioning hegemony of West in this article. Moreover it was also aimed to analyze what forms of counter hegemony are while mentioning ambiguity of construction. The suicide of protagonist in M. Butterfly which is inspired of Madam Butterfly opera, was also taken into consideration while questioning what identity and gender are. This article is qualitative and deconstructive analysis was uses in the analysis of the film as a text. It was found that no structures were ultimately constructed in the film, and that the established structures were constantly changing.
\end{abstract}

Keywords: Orientalism, Film Studies, Gender, Representation, M. Butterfly.

ORCID ID : 1: https:/ / orcid.org/0000-0002-3715-2089, 2: https:/ / orcid.org/0000-0003-2059-5585

E-mail : 1: canayguven@hotmail.com, 2: mserarslan@selcuk.edu.tr

DOI: 10.31122/sinefilozofi.358193

Recieved - Geliş Tarihi: 27.11.2017

Accepted - Kabul Tarihi: 09.06.2018 


\section{Giriş}

1993 yilında David Cronenberg tarafından yönetilen Jeremy Irons ve John Lone'nin başrolünü paylaştığı David Henry Hwang tarafından 1988'de yazılan aynı adlı tiyatro eserinin sinemaya uyarlaması olan M. Butterfly (M. Butterfly, David Cronberg, 1993) filmi sinemadaki egemen kadınlık/erkeklik rollerini yapı söküme uğratan bir anlatıma sahiptir. Bu açıdan filmin oldukça neo-formalist bir söyleme sahip olduğu iddia edilebilir.

Bu araştırmanın amacı kadınlık/erkeklik rolleri, Doğulu/Batılı olma biçimlerini ve tüm bu bağlamların oturduğu iktidarın nasıl oluştuğu sorununu ortaya koymaktır. Bu çerçevede çalışmada kimlik sorunu altında yapısökümcü okumaya başvurulacaktır. Böylece M.Butterfly filmindeki kadınlık/erkeklik hallerinin anlamının kayganlığı ve Doğu/Batı karşıtlı̆̆ının birbirine bağımlılığı iktidar olma/olamama ekseninde tartışılacaktır. Böylece bu araştırma bir gösterenin anlam üretmesini tamamlanmış bir süreç olarak ele almayarak, anlamın diğer gösteren ile sürekli ilişki içerisinde olduğu ve ertelendiği bakış açısından yola çıkmaktadır. Film özellikle kadın ve erkek olma halini iktidar, Doğu/Batı sorunsalı üzerinden yansıtır. Bu sebeple filmde kadın ve erkek olma biçimi tanımlanmaz, bu anlam sürekli ertelenir ve kabuk değiştirir.

Kadın ve erkek olma biçiminin sinemadaki egemen söyleminin cinsiyet araştırmalarına nasıl yansıdığına bakmak M. Butterfly'ı incelerken bir yol haritası oluşturacaktır. Kadınlık ve erkeklik hallerinin biyolojik yahut kültürel bir inşa olduğu sorusu tartışılagelen bir konudur. 1970'li yıllardan itibaren cins (sex) ve cinsiyet (gender) arasındaki farklılık toplumsal cinsiyet kavramı etrafında sorgulanmaya başlanmıştır. Kadınlık ve erkeklik hallerinin biyolojik olarak belirlenmediği ve toplum tarafından yüklenen sorumluluk, roller çerçevesinde şekil aldığını işaret eden toplumsal cinsiyet kavramı biyolojik farklılığı nasıl adlandırdığımız ve bu farklılıkları hangi sıfatlar, roller gibi değişkenler ile ilişkilendirdiğimiz ile ilgilidir. Bu çerçevede cinsiyetin biyolojik farklılıklardan ve genlerden kaynaklandığı yaklaşımı ile cinsiyete dair rollerin kültürel inşaya tabi olduğunu içeren toplumsal cinsiyet kavramiyla farklılıklarına bakmak, film boyunca kadın ve erkek olma biçiminin sürekli el değiştirdiği M.Butterfly filminin analizinde temel oluşturmaktadır. Bu sebeple öncelikle sex ve gender kavramlarının farklılıklarına değinmekte fayda var.

İngilizcedeki sex ve gender arasındaki fark ilk olarak 1950 ve1960'lardaki transseksüeller ile ilgili inceleme yapan İngiliz ve Amerikan bilim insanları tarafından ortaya konmuştur. 1950 ve 1960'lardaki o çalışmalardan bu yana ise sex'in kadın ve erkek olmayı cinsel organa göre belirlemede, gender'ın ise kültürel olarak inşa edilen rollere denk düşecek şekilde kullanımı giderek artmıştır (Esplen ve Jolly, 2006: 2). 1972'de cinsellik bilimci John Money ve Anke Ehrhardt cins ve cinsiyeti farklı kategorize ederek bu iki yaklaşımın farklı kullanımını yaygınlaştırmada etkili olmuştur. Money ve Ehrhardt cinsi fiziksel ve anatomik özellikler olarak tanımlamış, cinsiyeti ise psikolojik bir dönüşüm olarak kategorize etmişlerdir (FaustoSterling 2000:3). Bu bağlamda cins kadınlığın ve erkekliğin biyolojik, sabit ve değişmez olduğu varsayımına dayanırken, bir anlamda biyolojik farklılığın tek belirleyici olduğunu iddia eder.

Öte yandan, sosyal davranışların temelinde biyolojik özelliklerin olduğu görüşünü savunan sosyobiyolojik yaklaşım genlerin incelenmesinin gerekliliğini vurgulamıştır. Hayvanların ve insanların davranışlarında belirli bir evrimsel kökeni olduğunu, genlerin bu canlıların davranışlarını belirlemede önemli yeri olduğunu kabul etmekle birlikte, sosyobiyolojik yaklaşım her şeyin nedeninin genlere bağlandığı ve açıklamaların sadece 
genlere dayandığı determinist bir yaklaşımı içermez. Ancak yine de sosyobiyolojik yaklaşım özellikle insanların çoğalması ve çocukların yetiştirilmesi gibi konularda biyolojik ve sosyolojik durumların bir sentezinin yapılması gerekliliğini vurgulamaktadır (Burcu, 1998).

Cinsiyete dair rollerin bir ritüeller silsilesi olduğu ve biyolojik özelliklerin kadın ve erkek olma biçimlerinde bir anlam ifade etmediği görüşü ise toplumsal cinsiyet çalışmaları olarak ifade edilebilir. Toplumsal cinsiyet rolleri üzerinde saptamaları bulunan önemli bir isim olarak karşımıza Judith Butler çıkmaktadır. Butler (1988) cinsiyetin sabitleştirilmiş, kutuplaştırılmış, kopuk ve uzlaşmaz hale getirilmiş olduğunu vurgulamakta ve toplumun istediği şekilde cinsiyetini yaşamayan insanların cezalandırıldığını ve insanların toplumun yerleşik kodlarına göre davranmaya zorlanıldığını ifade etmektedir. Butler kadın ve erkek olmanın değişken/akışkan (fluid) bir şey olduğunu iddia eder. Butler (1988:519) bu iddiasında Simon de Beauvoir' ın “Kadın doğulmaz, kadın olunur” sözünden hareket eder. Fenomonolojik gelenek çerçevesinde, cinsiyetin asla durağan bir kimlik olmadığını, zamanla ve kalıplaşmış bazı hareketlerin tekrarı ile fark edilmeden oluşan bir kimliğe dönüştüğünü söylemektedir. Butler'ın (1988) ifade ettiği görüşler biyolojik deterministlerin ve sosyobiyolojik yaklaşıma sahip olan düşünürlerin savunduklarından oldukça farklıdır. Bu bağlamda cinsiyet rolleri genetik kodlama sonucunda oluşan bir kimlik değil, aksine ritüelleştirilmiş toplumsal hareketlerin toplamıdır. Çocukluktan itibaren bu toplumsal roller benimsenmeye başlanır. Zaman içinde bu hareketler kanıksanmış rollere dönüşür. Böylece kadınlar ve erkekler toplumsal cinsiyet rollerini sorgulamadan gerçekleştirirler.

M. Butterfly'da cinsiyete dair sorgulamanın toplumsal cinsiyet rolleri, ritüelleşmiş davranış kalıpları ile ilişkili olduğunu görmekteyiz. Bu çerçevede cinsiyet, kimlik ve iktidarın ne olduğu sürekli farklı bağlamlara tabi olur. Butler'ın (1988) ifade ettiği gibi bu roller tekrarlanır, iktidar el değiştirir ve cinsiyet asla durağan olmayan bir şekilde akışkan bir hal alır. Böylece filmde anlam devamlı bir yapı söküme uğrar.

\section{Filmin Konusu}

1993 yılında David Cronenberg tarafından yönetilen Jeremy Irons ve John Lone'nin başrolünü paylaştığı M. Butterfly, David Henry Hwang tarafından 1988'de yazılan aynı adlı tiyatro eserinin sinemaya uyarlamasıdır. Bu tiyatro eseri ise Giacomo Puccini'nin üç perdelik opera eseri Madam Butterfly'dan hem esinlenmiş hem de bu eserin ortaya koyduğu kadınlık/ erkeklik rollerini ters yüz eden bir anlatım sunmuştur.

Puccini'nin Madam Butterfly adlı eseri Amerikalı Pinkerton ile Japon geyşa Cio Cio arasındaki aşkı konu alır. Amerikan deniz subayı Pinkerton hayatına heyecan katmak amacıyla, 15 yaşındaki geyşa Cio Cio ile evlenir. Ailesi tarafından reddedilen Cio Cio, bir diğer ismiyle Madam Butterfly, o zamanki Japon yasalarının erkeklere istedikleri zaman geyşaları bırakabilme özgürlüğü tanıması ve Pinkerton'unn bu hakkı kullanması sonucunda, Cio Cio büyük bir aşkla bağlandığı Pinkerton tarafından terk edilir. Cio Cio tüm bu travmaların sonucunda intihar eder.

Puccini'nin eseri kadınlık ve erkeklik rollerinin bilindik anlatımının ardında iki farklı kültürün kopukluğunu sergilemesi ve iktidar sahibi Batılıya göre keşfedilmesi gereken Doğuyu resmetmesi açısından önemli bir eserdir. Operada ilişkiyi bitirenin Pinkerton olması ve aciz bir insan olarak Madam Butterfly'ın intihar etmesi Doğunun ve kadının ikincil önemde bir yere sahip olduğunun gösterilmesidir. 
David Cronenberg'in M. Butterfly adlı filmi ise Puccini'nin bu anlatımını adeta ters yüz etmektedir. Film Fransız diplomat René Gallimard ve Çinli opera sanatçısı Song Liling arasındaki aşkı konu almaktadır. 1960'larda geçen bu filmde, Gallimard sakin, huzurlu, itaatkâr ve bakire olduğunu düşündüğü Song'a büyük bir aşkla bağlanır. Rekabetin hakim olduğu bir iş ortamının getirdiği gerginliklerden arınmak ve huzur bulmak için gittiği Song'un evi René için oryantalist söylemin adeta bir yansımasıdır. Gallimard, Batı'nın gözünde egzotik ve gizemli bir yere sahip olan Doğu imgesini Song'un yanında keşfeder. Yirmi yıl kadar süren bu ilişkinin bir yanılsamadan ibaret olduğu filminin sonlarına doğru ortaya çıkmaya başlar. Çinli bir casus olan Song'un biyolojik cinsiyeti erkektir. Filmin son sahnesinde, casusluk suçuyla hapse düşen René üst üste yaşadığı hayal kırıklıkları nedeniyle intihar eder. René'nin son sahnede Geyşa kılığında olması ve kırık ayna parçasıyla intihar etmesi yalnızca Batılı gözünde oryantalizm algısının çöküşünü sergilemesi açısından önem arz etmez, aynı zamanda film boyunca sorgulanan kimlik, toplumsal cinsiyet rolleri ve iktidar ilişkileri gibi meseleler de bu sahne ile sorgulanir.

\section{Amaç ve Yöntem: M. Butterfly Filmi'nin Yapısökümcü Analizi}

Yapısöküm, Jacques Derrida, tarafından ortaya konulan, bir metnin içindeki anlamları ortaya çıarmak için kullanılan metin okuma stratejisidir. Yapısöküm, temel olarak metnin yapısal dokusunu parçalara ayırarak ele aldığı metin içerisindeki kavramlardan hareket eder. Bu kavramlar arasındaki ilişkide görünmeyeni ve örtük olanı yerinden söker ve ona yeni anlamlar kazandırır. Bu ters yüz etme işleminde hiyerarşik yapı bozulurken, yeni bir hiyerarşi ise kurulmaz (Akay, 1999:22). Derrida, Japon Bir Dosta Mektup'ta, dekonstrüksiyon sözcüğünün Batı́nın içinde tam olarak ne anlama geldiğini söylemenin olanaksızlığını belirtir (1999a: 187) ve Littré'de yapısökümün anlamının, -sözcüklerin dizilişini bozmak, -bir bütünün parçalarını birbirinden sökmek, -dilbilgisi terimi olarak dizelerin yapısını çözmek, -bir şeyin yapısını çözmek ve yapılanışını yitirmek olduğunu yazar (1999a: 188). Burada bir yapıyı sökme işleminde tamamen ortadan kaldırma amacı güdülmez, bundan ziyade metin içerisindeki ikircikli yapıların ve anlamların tespit edilmesi söz konusudur. Böylece yeniden ve sürekli inşa etme işlemi gerçekleşir. Diğer yandan, bir metin okuma tekniği olarak metin içerisindeki hiyerarşiyi yıkarken, yeni bir otorite alanı kurmaz. Dilin istikrarsızlığını, ikircikli yapısını ortaya koymak olarak da ifade edilen yapısöküm bir düşünce sistemi değildir (Sim, 2000:71). Metindeki kavramların tutarsızlığı ve ikircikli etkileşimi ortaya çıkarılması temel alınır (Sarup, 1997: 59). Fakat burada önemle belirtilmesi gereken şey yapısökümün bir şeyi yok etmek anlamında kullanılmadığıdır, bunun aksine sürekli bir inşa söz konusudur. Sözcüklerin tek bir anlamı olmadığını ve farklı şeylere de işaret ettiklerini ortaya koyan, metin içerisindeki kayganlığı ortaya çıkarmaya çalışan ve kavramların işaret ettikleri farklı bağlamlarını ortaya koyan bir metin okuma stratejisidir.

Yapısökümünden bahsederken Derrida'nın yapı ile neyi kast ettiğine kısaca değinmek anlamlı gözükmektedir. Derrida'ya göre yapı kavramı Batı bilimi ve felsefesiyle yaşıttır (1999b: 167). Burada yapı kavramı, bir merkez ve sabit nokta belirlemek anlaminda kullanılmaktadır. Derrida' ya göre merkez "ard arda ve düzenli/kurallı bir tarzda farklı biçimler almıştır" (1999b: 168). Derrida temelin, ilkenin veya merkezin tüm adları (eidos, arche, telos, energia, ousia [öz, varoluş, töz, özne] aletheia, aşkınlık, bilinç, Tanrı, insan vb.) daima sabit bir mevcudiyeti olduğunu belirtir (1999b: 168). Fakat merkez anlamını tarih içerisinden alır ve yapının yapısallığı 
düşünülmeye başlandığı zaman kopuş söz konusu olur. Derrida bir merkezin olmadığını ve merkezin bir mevcut-olanın biçimi içinde düşünülemez olduğunu öne sürmüştür. Bu çerçevede merkezin doğal bir mahallinin olmadığı, sabit yer değil, bir işlev, içerisinde gösterge ikamelerinin sonsuza dek oynadığı bir tür yer-olmayan olduğunu ifade etmiştir (1999b: 168). Böylece Derrida (1999b) aşkın gösterilenin yokluğunun, anlamın oyununu sonsuza dek uzattığını ifade eder. Derrida'nın bütün göstergelerin bizi başka göstergelere götürmesine yaptığ1 vurgu, onun ünlü 'metnin dışında bir şey yoktur' (Derrida, 2010: 242) yaklaşımının zeminidir.

Metin içerisindeki anlam sürekli çelişkiler içerisindedir ve sabit bir noktadan uzakta, ikirciklidir. Anlam dolayısıyla belirsizlikler taşır ve Derrida'nın (1999b) merkezin olmadığı düşüncesi bu noktada anlam kazanır. Metinin anlamı metinde olmayan ve söylenmeyen ile bulunabilir ve bu hususta herhangi bir merkezden, diktonomiden bahsedilemez. Kisacası hiçbir metnin tek ve kesin bir anlamı yoktur. Anlam sürekli inşa içerisinde var olur. Burada metin ve filmde metin konusuna biraz açılık getirmek anlamlı gözükmektedir. Metin kavramı, etimolojik olarak İngilizce 'de doku yahut dokuma fiilinden türemiştir. Barthes'a göre metin (1977:146) yazarın mesajını açığa çıkaran kelimeler dizisi değil, çeşitli yazımların harmanlandığı çok boyutlu bir uzamdır. Film de bir metin olarak ele alındığında farklı uzamları ve anlamları içerisinde barındırır. Böylece anlam inşa edilen bir süreci imler. Bu süreçte bir hiyerarşi yoktur ve anlam çok boyutludur. Bu yüzden, film metni yapısökümcü bir okumadan faydalanılmaya açıtır. Filmi bir metin olarak değerlendirdiğimizde metin sisteminden ne kastettiğimizi biraz açıklamak gerekmektedir. Metz'e göre (1974: 103) metin sistemi kodları yerinden eden, her bir kodu deforme eden, bu süreçte bu kodların birbirinin yerine geçtiği bir süreçtir. Kodların bu alışverişi, anlamın el değiştirmesi yine filmde yapısökümcü analizin kullanılmasında etkili olmaktadır.

Yapısökümcü çözümleme film analizinde sessiz ve karşı konulamaz bir varlık olarak süregelmiştir. Bu varlık Derrida'nın “iz, dağılma, logosantrizm, aşırılık," gibi kavramsal düzlemde film eleştirisi söyleminde dolaşıma girmiştir (Stam, 2014: 192). Esasen Derrida yazılarında ne film teorisinde yapısökümü, ne de bunun nasıl uygulanacağını tartışmıştır (Rajyavardhan ve Sharma, 2017 : 23), fakat film analizinde yapısöküm ileriki dönemlerde kullanılagelmiştir, çünkü film de bir metin olarak logosentrik bağlamda/ temelde ele alınmaktadır. Peter Brunette (1986) film eleştirisinde bir araç olarak yapısöküme başvurulabileceğini vurgulamıştır ve tıpkı basılı bir metin gibi filme de yapısöküm okuma yapılabileceğinin üzerinde durmuştur. Bu çerçevede filmdeki diyaloglar, karakterler, müzik gibi ögeler bir anlam oluşmasında önemlidir ve bu anlam da yapısöküme tabi tutulabilir. Bu bağlamda yapısökümün sinema teorisinde ve analizinde, bir okuma biçimi olarak karşımıza çıtı çelişkili olduğu fikri dikkate değerdir. Bir metin olarak film yapısöküme tabi tutulduğunda, analizde film metnindeki kodlar eklemeli bir listeden ziyade, filmin kendi metnini yazdığı, değiştirdiği, kodların birleştiği ve bazı kodların diğerine karşı kullanıldığı yeniden yapılandırma çabası önem kazanır. Metinsel sistem böylece birbirini etkilemeleri ve birbirleri yerine geçmelerini içeren kodların sürekli değiştiği bir durumdur (Stam, 2014: 193). Nesnesinin kim olduğuna bağlı olarak politik bileşim değerini kaydırır ve sistematik bir biçimde -erkek/ kadın, Batı/ Doğu, siyah/beyaz gibi ikili hiyerarşilere meydan okur (Stam, 2014: 195). 
M. Butterfly filminin yapısökümcü bir okumaya tabi tutulmasının sebebi filmdeki kadın/erkek ve Doğu/Batı ikiliklerinin sürekli bir zincirleme ile el değiştirmesidir. Filmde anlam ertelenir, göstergeler sürekli birbirleri sayesinde anlam kazanır, kadınlık/erkeklik ve Doğu/Batı kavramları muğlak kalır. Anlamın böylesi oynak olması ve hiyerarşik bir yapıdan ziyade, iktidar olanın ne/kim olduğunun askıda kalması filmin yapısökümcü bir analiz ile ele alınmasını gerektirmiştir. Bu çerçevede M. Butterfly'da Kimlik Sorunu, M. Butterfly'da Oryantalist Söylem, Erkeklik Mücadelesi ve İktidarın İkircikli Yapısı, M. Butterlfy'da Haz ve Özdeşleşme Sorunu başlıkları birer parametre olarak belirlenmiş ve filmin yapısökümcü okuması yapılmıştır. Burada metin içerisindeki ikircikli hal ve el değiştiren anlamlar ile bunların yerinden ediliş biçimlerinin ortaya çıkarılması amaçlanmaktadır.

\section{Bulgular ve Yorum}

Bu bölümde iktidar, kadın/erkek ve Doğu/Batı ile filmdeki özdeşleşme sorunu incelenmiştir. M. Butterfly'da Kimlik Sorunu, M. Butterfly'da Oryantalist Söylem, Erkeklik Mücadelesi ve İktidarın İkircikli Yapısı, M. Butterlfy'da Haz ve Özdeşleşme Sorunu birer alt başlık olarak belirlenmiş ve yapısökümcü okumayla sürekli el değiştiren yapılar/anlamlar ortaya konulmaya çalışılmıştır.

\section{Butterfly'da Kimlik Sorunu}

M. Butterfly'da kadın/erkek ve Doğulu/Batılı kimlikleri ters yüz edilerek sunulmaktadır. Filmin ismi M. Butterfly'da M. kısaltmasının mösyö mü, madam mı olduğu bu sorgulamamanın bir izdüşümüdür. Filmin başkarakterlerinden Song'un bir tiyatro sanatçısı olması ve René' nin geyşa kılığına girerek hapishanedeki intiharı izleyiciyi kimlik ve performans diyalektiğinde düşünmeye sevk eder. Film boyunca karakterlerin karş1lıklı inşa ettikleri kimliklerinin yıkılması, kadınlık ve erkeklik rollerinin alt üst olması, Batılı bir erkeğin gözünde Doğulu bir kadın algısının yerle bir edilmesi filmin kimlik sorunsalı üzerinden incelenmesini gerektirmektedir.

Tıpkı yüzümüzü aynadaki yansımamız olmadan göremediğimiz gibi, bireysel ve kolektif kimlikler de farkına varma ve karşılıklı etkileşime muhtaçtır. Bu yüzden kimliğin oluşması için ötekine ihtiyaç vardır. Kimliği benzerlik, aynı olma haliyle ilişkilendirmek anlamsızdır. Böylesi bir yaklaşımdan ziyade kimlik özdeşleşme haliyle ilişiklidir ve asla tamamlanan bir süreç değildir. Öteki ile özdeşleme yahut kendini tarif etme biçimi olarak kimlik inşasında sınırlar belirsizdir (Hall, 1997: 47-48). Başka bir ifadeyle kimlikler sabit ve homojen bir yapıdan oluşmaz, kimliklerin oluşmasında/anlam kazanmasında karşılıklı etkileşim devamlıdır ve yeniden yaratılır.

Kimlik inşasının tek taraflı olmadığını öteki ile yaşanılan etkileşimin bir süreç olduğu ve bu inşanın da performansa dayalı olduğunu ortaya koyan Goffman (2014) bu etkileşimi benliğin sunumu olarak tarif eder. Goffman (2014) bireylerin gündelik yaşamda belli kimliklere büründüklerini ifade eder. Goffman'ın yaklaşımı kendisinin geliştirdiği, hayatın bir tiyatro sahnesi olduğu ve herkesin bir rolü performe ettiği dramaturjik teoridir. Tiyatroda oyuncuların bir metni oynamaları ile gündelik yaşam arasında benzerlik kuran Goffman (2014) her gün sahnelenen gündelik yaşamdaki tekrarlanan toplumsal rolleri rutinler olarak ifade eder ve bu rutinlerin gerçekleştiği yeri ise sahne önü olarak adlandırırdır. Goffman'nın bir de sahne arakası olarak ifade ettiği bölge vardır ve burada insanlar kendi başlarınadır. 
$\mathrm{Bu}$ kimlik inşasının tiyatro sahnesine benzediği performansa dayalı etkileşimli sistemde en temel meselelerden birisi kimliğin sahibinin kim olduğudur. Zira bu yaklaşıma göre kimlik aktörlerin tek başlarına ellerinde tuttuğu bir şey değildir.

M. Butterfly'da Song ve René'nin kadınlık ve erkeklik kimliklerinin birbirleriyle kurdukları etkileşimle gerçekleştiğini ve yıkıldığını görmekteyiz. Bu nokta ise kadın ve erkek olmanın biyolojik mi yoksa toplumsal mı olarak inşa edildiği sorusunu akıllara getirmektedir. Zira filmin sonunda Song' un bir erkek olduğunun ortaya çıkması ve René 'nin kimono kıyafeti ile bir geyşa kılığında intiharı bu sorgulamanın temelini oluşturmakladır. Bu kıyafetler, hem kimliklerin değiş-tokuşunu hem de toplumsal cinsiyet rollerini sembolize etmektedir. Film boyunca biyolojik cinsel kimlik açısından kadın ve erkek olarak yansıtılan karakterler filmin sonunda bir birlerine dönüşür. Bu durum ise cinsel kimliğin etkileşime tabi, kültürel ve ritüelleşmiş davranışlar silsilesi olduğunu akıllara getirir.

Filmdeki cinsiyet rolleri ve kimlik sorunu Song ve René açısından incelenecek olunursa René ve Song bir fantezi dünyasında, yanılsamalarla yaşamaktadırlar. Bu noktada, kimlik krizi kişinin kendisinden beklenenleri gerçekleştirememesi ya da beklenenlerin dişında hareket etmesi durumunda gerçekleştiğini akılda tutmakta fayda var. M. Butterfly filminde görünen kimliklerle bu kimliklerin arkasındaki asıl kimlikler arasındaki gerilim oldukça dikkat çeker. Beyaz, Batılı ve heteroseksüel bir karakter olan René aslında birçok ikilemlerle doludur. René gerçekte eşine ihanet etmektedir. Doğulu, sakin ve uysal bir kadın olduğunu düşündüğümüz Song ise aslında bir casus ve erkektir. M. Butterfly filminde görünenin arkasında tamamen farklı bir tablo bulunmaktadır. Bu durum kişinin görünen kimliğinin arkasında başka bir gerçeklik yatabileceğini anlatır niteliktedir. Cronenberg'in bu filmde göstermiş olduğu şey toplumun René ve Song' dan beklediği kimliklerle aslında onların taşıdıkları kimliklerin ne kadar farklı olduğudur. Kişinin ondan beklenenleri gerçekleştirememesi ve yaratmış olduğu illüzyonunu fark etmesi karşısında aciz kalması sonucunda yaşadığı kimlik kriziyle René intihar eder.

Cronenberg' in filminde Song' un bir sahne sanatçısı olması toplumsal cinsiyet rolleri ile ilgili çağrışımlar yapar. Kadın olmanın biyolojik değil, toplumsal bir olgu olduğunu "Kadın doğulmaz, kadın olunur." sözü ile ifade eden Simon de Beauvoir gibi Butler (1988) da cinsiyeti determinist bir bakış açısıyla tanımlamaz ve cinsiyet rollerinin performe edilen bir olgu olduğundan bahseder. Cinsiyeti performe edilen bir şey olarak ele alındığında, bunun bir yapı değil karşılıklı roller ile inşa edilen bir süreç olarak değerlendirildiğinde, filmin analizinde Song'un bir müzikal sanatçısı olması ve René'nin hapishanedeki son performansı metaforik okumaya açık olduğu görülmektedir. Burada karşımıza kimliğe dair iki farklı performans çıkmaktadır. Song esasen olmadığı bir kişinin cinsiyetini performe etmektedir. Diğer bir taraftan Song'la yaşadığı aşkın gerçek yüzünün ortaya çıkmasının ardından vatana ihanetle yargilanan ve hapse mahkum edilen René'nin hapishanede "kariyerimin devamı" performansı dediği bir gösteri gerçekleştirmesi de bir diğer kimlik performansıdır. Peruk takan, oje süren ve kimono giyen René tamamen farklı bir kimliğe bürünür. Bu kimlik onun sahip olduğunu zannettiği Madam Butterfly imgesidir. Bu filmde olduğu gibi, hayat bir tiyatro sahnesidir ve bu sahnede kimlikler ve cinsiyet rolleri performe edilir. Tüm bunlar bize Goffman'ın (2014) sahne önü ve arkası davranışlarını anlatır niteliktedir. Filmdeki tiyatro sahnesi de bu yaklaşımın bir izdüşümü olarak okunabilir. 
M. Butterfly'daki bir diğer kimlik bunalımının tezahür edişi ise René'nin fantezi dünyasıdır. Filmin başlarında Madam Butterfly adlı operayı seyretmeye giden René burada Song' un performansından oldukça etkilenir. Belki dehayatında bu operayı ilk kez izlediği için bu denli etkilenen René, oyunla kendisini özleştirir. Bir anlamda operadaki Pinkerton karakterine büründüğü yanılsamasına kapılan René kendi fantezi dünyasını yaşamaya başlar. Hoffman (1997) da belirttiği gibi René yaratmış olduğu güvenli fantezi dünyasına bağlı kalır. Bir kadın tarafından koşulsuz olarak sevilerek, itaat edilmenin imkansız olduğu kendi kültüründen uzaklaşarak, görsel ve işitsel unsurlarla zenginleştirilmiş Madam Butterfly'ın aşkının anlatıldığı operanın büyüsüne kapılır ve hikayedeki ütopik ilişkiyi Song ile yaşayabileceğine inanır. Oysa Batılıların tanımadıkları bir kültür hakkında gerçek olduğunu sandıkları gizemli ve egzotik masaldan haberdar olan Song, bir erkek olarak başka bir erkeğin zayıf noktalarını bildiği için René'yi duymak, inanmak ve yaşamak istediği illüzyonun içine dâhil eder. Eğitilmeyi beklediğini düşündüğü Çinli sevgilisi tarafından yüceltildiğine, sorgulanmadan kabul edildiğine ve itaat edildiğine inanan René kendi toplumunda yaşayamadığı erkekliğini var sandığı bir yanılsama içinde gerçekleştirdiğini zannederek, aslında Komünist rejimin casusu olan Song'a istediği bilgileri vermektedir. Song' un gerçekte bir Çin casusu çıkmasının ardından, cezaevi aracında üstündeki kıyafetleri çıkaran ve gerçek kimliğini gördüğü Song'a “ Benim Butterfly'ım mısın?" diye sorar. "Bütün uzun giysilerin altında ben vardım. Beni gerçekten hiç sevmedin." diyen Song'a "Ben bir erkeğin yarattığı kadını sevmiştim. Ben bir yalanı sevmiştim" der. René'nin de dediği gibi kendisi aslında bir yalanı sevmiş ve kendisini kandırmıştır.

Filmin son sahnesindeki René'nin iç hesaplaşması ve toplumla yüzleşmesi çeşitli yönlerden irdelenebilir. Vatana ihanet suçundan hapse mahkûm olan René diğer mahkûmlara sunmak üzere bir gösteri hazırlar. Kariyerinin en büyük gösterisini hazırlamak üzere peruk, kimono, ruj ve ayna gibi kostüm ve aksesuarlarla sahneye çıkar. Parmakları ojelidir. Gösterisine erkek kimliğiyle başlar ve ünlü olduğunu çünkü tüm Fransa'yı güldürdügünü söyleyerek yaşadıklarına dikkat çeker. Bu sahnede söylediği “ Beni tanıyorsunuz değil mi? Neden? Çünkü ben ünlüyüm. İnsanları güldürüyorum. Bütün Fransa'yı güldürdüm. Ancak gerçekten anlasaydınız gülmezdiniz. Tam aksine sizin gibi erkekler kapımı aşındırmalı, sırlarımı öğrenmek için yalvarmalılar. Bence René Gallimard mükemmel bir kadın tarafından tanındı ve sevildi." Burada René yaşadığının bir yanılsamadan ibaret olduğunun farkında değildir. Hala mükemmel bir kadın tarafından tanındığına ve sevildiğine inanmaktadır. Fakat diğer bir yandan ise tüm Fransa'yı güldürdüğü gerçeğiyle yüzleşmiştir. Ünlü tiradına şu şekilde devam eder.

Doğulu deyince aklıma gelen görüntüde kimono giyen değersiz yabancl şeytanların, aşkl için ölen mükemmel kadın olmak için doğan ve yetiştirilen, onlara verdiğimiz her cezayı kabullenip aşkın gücüyle tekrar yeniden ayağa kalkan ince kadınlar var. Bu hayatım haline gelen bir görüntü. Hatam basit ve kesindi. Sevdiğim adam değersizdi. İkinci bakışı bile hak etmiyordu. Ama bunun yerine ona aşkımı verdim. Bütün aşkımı. Aşk gözlerimi kör etti. Bu yüzden aynaya baktığımda gördüğüm tek şey Doğunun görüntüsü görüyorum. Badem gözlerinin derinliklerinde hala kadınlar. Bir erkeğin aşkı için kendisini feda etmeye hazır olan kadınlar. Aşkın hiçbir değerinin olmadiğı adamlar için bile. Onurlu bir ölüm, onursuz bir yaşamdan iyidir. Sonunda Çin'den uzaktaki bir hapishanede onu buldum. Benim adım René Gallimard, aynı zaman da Madam Butterfly olarak da tanınırm. 
Bu tiradını gerçekleştirirken bir geyşa gibi giyinmeye başlayan René, gözündeki Doğulu, uysal, itaatkâr ve egzotik kadın imajına dönüşmeye başlar. Madam Butterfly adlı opera eserini ilk kez izlediği gün bu eserdeki Pinkerton karakterine dönüştüğü yanılsamasına kapılan ve fantezi dünyasında yaşamaya başlayan René, karşılaştığ gerçeklerle mücadele edemez. Bu noktada hayalindeki mükemmel kadın olan Madam Butterfly'a dönüşür. René'nin yaşadığı bu kimlik bunalımı onun gerçeklerle mücadele edememesinden kaynaklanır. Hayatın gerçeklerine karşı sürekli başka bir karakterin özelliklerini edinir. İlk olarak Amerikan deniz subayı Pinkerton gibi yaşamaya başlar ve en sonunda ise Madam Butterfly olarak intihar eder.

Hoffman (1997) René'nin yaşadığı kimlik bunalımının Song'un yaşadığından çok daha fazla olduğunu belirtir. Hoffman'a göre René ve Song'un sergilediği roller ve aralarındaki sınırlar sadece onların birbirleriyle olan ilişkilerini belirlemekle kalmaz aynı zamanda bu iki karakterin kimliklerini oluşturur. Song'un aciz ve Doğulu bir kadın olması René'nin fantezi dünyasının vazgeçilmezidir. René'nin baskın Batılı erkek kimliği, Song'un Doğulu teslimiyetçi kadın kimliğiyle şekillenir. Song'un aslında Doğulu, egzotik, itaatkar ve uysal bir kadın olmaması ve bunun bilincinde olması onun daha az kimlik krizi yaşamasına neden olur. Song ne istediğini bilen ve bu doğrultuda hareket eden bir karakter çizmektedir. Yoldaş Chin'e Amerikalıların Vietnam'a ne kadar asker çıkaracağından bahsettiği sahnede, Chin ona René orada değilken bile neden bir rol yapmaya devam ettiğini sorar. Song ise ona "Yoldaş büyük proleter duruma daha iyi hizmet edebilmek için, sık sık yalancılığımla ilgili pratikler yapiyorum. Bu kostümden nefret ediyorum. Başka birisi olmak için elimden gelenin en iyisini yapıyorum" Song'un bu cümlesinden anlaşılabileceği üzere, Song ne yaptığını bilmekte ve rolünün farkındadır. Bu durum ise Song'un tüm yaşanılan bu olaylardan daha az etkilenmesinin sebebidir, zira filmin sonunda René intihar ederken, Song bambaşka bir karaktere dönüşümünü gerçekleştirir. Bir anlamda kozasından çıkar.

M.Butterfly'daki erkeklik ve kadınlık kimlikler etken olma ve edilgen olma hali üzerinden yansitmaktadır. Filmin sonuna kadar Song'u kadın ve edilgen (passive) olarak seyrederken, René etken (active) ve erkek olarak resmedilmiştir. Film, her ne kadar kadınlık ve erkeklik rollerini alt üst eden ve sıra dışı bir söyleme sahip olsa da filmin en sonunda basmakalıp roller yeniden inşa edilir. Filmin başında Doğulu, itaatkar ve edilgen olarak gösterilen Song, filmin sonunda bir Batılı gibi giyinen acımasız bir erkeğe dönüşür. Yine filmin başında başarılı, güçlü, Batılı, beyaz ve heteroseksüel olarak resmedilen René, filmin sonunda güçsüz, Doğulu, kandırılmış, edilgen ve zavallı bir kadına dönüşür. Kimono giyen Song'un takım elbise giymesi ve takım elbise taşıyan René' nin Doğulu bir kadın gibi giyinmesi cinsiyet rollerinin de tıpkı kıyafetler gibi değişken olduğuna gösterir. Biyolojik olarak erkek olan her iki karakterin tutumları sömürme, aldatma ve hükmetme duygularıyla şekillenir. Bu noktada Cronenberg toplumsal cinsiyet rolleri açısından umutsuz bir tablo çizmiştir.

\section{Butterfly'da Oryantalist Söylem, Erkeklik Mücadelesi ve İktidarın İkircikli}

\section{Yap1s1}

M. Butterfly sadece kadınlık ve erkeklik rollerini alt üst etmesi bakımından önemli bir eser değildir, aynı zamanda oryantalist söylemi de sorgulamaktadır. Batı ve Doğu neresidir? Uzakdoğu nereye göre uzaktır? Coğrafi konum olarak Batı ve Doğu durduğumuz yere ve aldığımız referans noktasına göre değişiklik gösterir. Uzak Doğu olarak adlandırdığımız yerin nereye göre uzak olduğu sorunsal bir alandır. Örneğin, Japonya Amerika'nın Batısında 
yer alırken Doğu olarak tasvir edilen bir yerdir. Bunun ötesinde, Batı ve Doğu sadece coğrafi konumlar değildir. Batı ve Doğu kültürleri, insan topluklarını ve farklı yaşam biçimlerini de temsil ederler. Coğrafi konum olmaktan daha fazla anlamlar taşıyan Batı ve Doğu M. Butterfly filminde bir söylem biçimi olarak oryantalist perspektifi hem yermekte hem de bir anlamda yeniden inşa etmektedir, bu yüzden söylem bir türlü inşa olmaz. Oryantalist söylemde, Batı kendisini öteki üzerinden yani Doğu üzerinden tanımlar. Öteki olarak tanımlanan Doğu bir anlamda Batı'nın varoluş sebebidir. Bu noktada kısaca oryantalist söylemin ne olduğuna değinmek faydalı olacaktır.

Oryantalizm etimolojik olarak Latince güneşin doğduğu yer anlamında kullanılan oriens teriminden türemiştir. On dokuzuncu yüzyılda gelişen bir bilim dalı haline gelen oryantalizm, Doğu dilleri, dinleri, tarihleri ve kültürlerini inceleyen Doğu araştırmalarını kapsayacak şekilde kullanılmıştır (Uluç ve Soydan, 2007: 37).

Oryantalizmin felsefesi, ötekini tanımlayıp onun üzerinden kendisini tanımlama üzerine kuruludur. Bir anlamda, insan ne olduğunu söylerken, aslında neler olmadığını da söylemiş olur. Oryantalist söylem önce Doğuyu tanımlayıp onun üzerinden Batı tanımını gerçekleştirir. Bu söylemde Doğu mistik, itaatkâr, egzotik ve gizemlidir. Batı ise rasyonel, güçlü, medeni ve hükmedendir.

Oryantalizm ile ilgili düşünceleriyle oldukça önemli bir sosyolog olan Edward Said (2003) kitabında tek bir oryantalizm tanımı yapmaz. Said üç farklı şekilde oryantalizmin çerçevesini çizer. Birincisi, Doğu'ya yönelik çalışmalardır. Bu tanım Doğu dünyasının dinlerini, kültürlerini, dillerini ve tarihlerini inceleyen Doğu araştırmalarıdır. İkincisi, Edward Said 'in (2003) eserinde Batı' da Doğuyla ilgili fikir üretenlerin öykülerini, şiirlerini, yazılarını kapsayacak şekilde ele alınır. Bu tanımda oryantalizm Doğu'yu konu edinen kurumların tümünü kapsamaktadır. Üçüncü tanıma göre Oryantalizm Doğu hakkında saptamalar yaparak, onu tanımlayarak eğiterek ve ona hükmederek Doğuyu yeninden yapılandırmayı hedefleyen bir Batı şekilciliğidir. Doğu ile kurulabilecek olanaklı ilişkiler içinde Doğu'dan üstün olduğu fikrine dayalı Batı hegemonyası Oryantalizmi oluşturmaktadır. Özetle, Doğu ve Batı arasındaki ontolojik ve epistemolojik ayrımı kapsayan bir düşünce biçimi olduğu ifade edilebilir.

Oryantalizmin erkeklere özgü bir inceleme alanı olduğunu belirten Said, pek çok meslek topluluğu gibi Oryantalist düşünce de ele aldığ1 konuları cinsiyetçi ve ön yargılı incelediğine dikkat çeker ve edebi eserlerde kadınların eril bir hayal gücünden çıktıklarını ifade eder (Said, 2003: 220).

Oryantalist söylemde Doğu aciz, egzotik, keşfedilmesi gereken duygusal bir kadın ve Batı da hükmeden, medeni ve akılcı bir erkektir. M. Butterfly'da akılını kullanan, Doğulu bir kadına hükmeden ve erkekliğini bu anlamda ispatladığını sanan René ile aciz, duygusal ve ilgiye muhtaç Song arasındaki aşk Batı' nın Doğu'yu keşfettiği bir tutkudan daha fazlası olarak yansitılmıştır. René'nin kendini erkek gibi hissetmesini sağlayan şey onun Song'un efendisi olduğu yanılsamasına bağlıdır. Kadın/doğu ve Batı/erkek karşıtlığıyla ilgili René ve Song'un arasında geçen şu diyalog ilgi çekicidir. 
Bu en sevdiğiniz fantezilerden değil mi? Uysal Doğulu kadın ve kötü beyaz adam. Şöyle olduğunu düşünün, sarışın bir ponpon kız iş adamına aşık olsa ne dersiniz? Adam onunla evlenir ve sonra üç yıllığına memleketine gider. Bu süre içinde kız onun resmine bakıp dua etse ve genç bir Kennedy'nin evlenme teklifini reddetse, sonra kocasının yeniden evlendiğini öğrendiğinde kendisini öldürse, bu kızın bir akıl hastası olduğunu düşünürsünüz değil mi?

Song'un bu sözleri Batı'nın gözündeki itaatkar, teslimiyetçi ve sadık Doğu kültürü algısını oldukça net bir şekilde özetlemektedir. Rasyonel Batı ile uysal ve egzotik Doğu'nun karşılaştırıldığı bu sahne filmdeki oryantalist söylemin bir sorgulamasıdır. Filmde nerenin doğu ve batı olduğu iktidar kurma ve hükmetme üzerinden şekillenir. Doğu'nun gizemli, itaatkar ve sadık tasviri ile Batı' nın hükmeden, ukala ve rasyonel tavrı değiş-tokuş edilmektedir. Böylece bu kavramlar el değiştirerek bir hiyerarşi üzerinden tanımlanmaz. Bundan ziyade Doğu ve Batı bir biriyle ilişkili ve döngüsel bir zincir ile bağlıdır.

Oryantalist söylemde Doğu/kadın ve pasif, Batı/ erkek/ ve aktif olarak tasvir edilmektedir. Bu tasvirin ise egemen eril bakış ile oluşturulduğu ifade edilebilir. M. Butterfly' da sürekli René'nin bakışlarının Song'un üzerinde olduğu, onu baştan aşağı süzdüğü ve özetle ifade etmek gerekirse René'nin gözleriyle Song'un üzerinde bir tahakküm kurduğunu görmekteyiz. Filmde bu bakış Batı'nın Doğu kültürünü yukarıdan bir tavır ile incelediğini akla getirmektedir. Batı'nın Doğuya ve Doğu'nun Batı'ya dönüşmesi ile tahakküm ve bakış meselesinde farklı bir bağlam ortaya çıkar. René'nin Batılı kimliği Song'un Doğu'lu kimliği ile değişir. Song'un Batılı kimliğe dönüşmesi ile René'nin gözlerinin içerisine daha dik baktı̆̆ı ve bakışlarını ondan kaçırmamaya başladığı görülmektedir. Song'un cezaevi aracında René'den gözlerinin içerisine bakmasını istemesi bir taraftan onun başka bir kimliğe büründüğünü gösterirken, diğer taraftan tahakküm ve iktidarın Song'un eline geçtiğini göstermektedir. Filmde kimliklerin dönüşmesiyle bakışların da değiştiği ve Batı/erkek ve aktif, Doğu/Kadın ve pasif rollerinin değiş tokuş edildiği görülmektedir.

Filmde Batılı, acımasız, beyaz ve heteroseksüel imgesinin kırılma süreci Song'un mahkeme salonuna takım elbise ile geldiği sahneyle başlar ve René'nin geyşa kılığına girerek hapishanede intihar ettiği sahneyle son bulur. Yirmi yıl boyunca sadakatinden bir an bile şüphe etmediği, Doğulu, zayıf, güçsüz, korunmaya ve eğitilmeye muhtaç, narin, kırılgan kelebeğinin aslında Çinli bir erkek casus olduğunu öğrenen René cinsel ve sosyal kimliğini sorgulama sürecine girer. Yaşadığı yanılsamanın sebebinin bir kadın tarafından koşulsuz sevilmek ve itaat edilmek arzusu olduğunun fark eden René, bu zayıf noktasının yine başka bir erkek tarafından kötüye kullanılmasıyla içine düştüğü durumu kabullenemez. Yaşadıkları onun Batılı kimliğini sorgulamasına yol açar. René kendi güçlü ve erkek kimliğini karşısındaki aciz kadın kimliğinden türetir. Yalnızca Batı değil, Batı kadar Şark da kendisine gerçeklik ve mevcudiyet kazandıran bir düşünme geleneğini ve ortak imge dağarcığı vardır. Bu şekliyle Batı ve Doğu birbirini destekler ve yansıtır (Said, 2003 :14). Sosyal ve cinsel kimliği sadece Doğulu Song'un yansıttıkları ile şekillenebilir ve sürdürülebilir olan René gibi Song da Doğulu ve sadık kimliğini René'nin varlığından alır. Aslında bu iki karakterin ontolojik alanları birbirlerine bağımlıdır. René' nin kimlik krizi içerisine girmesiyle o vakte kadar inşa ettiği tüm gerçeklikler birbiri ardına yıkılmaya başlar. Batılı, egemen, güçlü ve akılcı kişiliğinin özelliklerini yitirmeye başlar. İlk olarak erkek kimliğinden feragat eder ve bir kadın olur. İkinci değişim ise Batılı kimliğini terk edip bir geyşaya dönüşmesidir. İhanete uğramasıyla sahip olduğunu zannettiği 
gerçekliklerin yalandan ibaret olduğunu anlayan René aklını da yitirmiştir. René'deki tüm bu değişikliklerin zıttı Song'da tezahür bulur. Song'daki ilk değişiklik onun erkek kimliğine bürünmesi ve Doğulu geleneksel elbiselerini terk ederek takım elbise giymesidir. Song duygusal imajını terk eder ve rasyonel bir Batılı kimliğine bürünür. Said'in (2003:15) de dediği gibi Doğu ve Batı birbirini yansıtmıştır.

Said Doğu ve Batı arasındaki ilişkinin bir egemenliğe tabi olduğunu ve bu durumun derecesi değişen bir hakimiyeti kapsadığını ifade eder. Filmde, tıpkı Said'in (2003) Doğu ve Batı arasındaki egemenlik ilişkisini tanımladığı gibi karmaşık bir süreç gerçekleşmiştir. Kadın/ Doğu ve Erkek/Batı arasındaki ilişki bir egemenlik ve hükmetme üzerinden anlatılmıştır. René ve Song'un kimlik değiş tokuşları bu iktidar ilişkilerini değiştirmemiştir. Doğu zayıflık, acizlik ve egzotiklik, Batı ise güçlülük, rasyonellik ve hareketlilik çerçevesi içerisinde ele alınmıştır. Bu açıdan bakıldı̆̆ında, Hoffman (1997) da belirttiği gibi M. Butterfly her ne kadar basmakalıp erkeklik ve kadınlık rollerini yapısöküme uğratan bir yaklaşım sergiliyormuş gibi gözükse de, filmin sonunda basmakalıp kadınlık ve erkeklik tekrar inşa edildiği iddia edilebilir. Fakat René' nin intiharı bir diğer yandan özgürleşme biçimi olarak da okunabilir. Bir yandan bu tavır toplumsal cinsiyet rollerinden bir çıkışı da temsil etmektedir.

Filmin başında Doğulu, durağan, itaatkar ve keşfedilmeyi bekleyen Song filmin sonunda Batılı ve acımasız erkeğe dönüşürken, René aklını yitirmiş, terk edilmiş ve hüzün dolu bir kadına dönüşür. Cronenberg, iktidar ve güç ilişkisi bakımından Doğu ve Batı'nın konumlarını değiştirir. Filmdeki bu oryantalist söylemin kendisini erkeklik mücadelesi olarak gösterdiği ifade edilebilir. M. Butterfly filminde erkekler iktidara, güce ve yönetmeye tapar gösterilmektedir. Hem René'nin hem de Song'un adeta yüzlerine takmış oldukları erkeklik maskesinin ardında, hükmetme, muhtaç etme ve işkence etme fantezileri yatmaktadır. Erkeklik dünyası bir anlamda oldukça acımasız yansıtılmaktadır.

M. Butterfly' daki egemen erkeklik yahut başka bir ifadeyle hegemonik erkeklik biçimine meydan okunmaktadır. Hegemonya kavramı iktidarın zorla dayatılmasından veya kaba kuvvetten ziyade insanların rızasına dayalı olmasını işaret eder. Hegemonya toplumdaki en görünür kültürel egemenlik biçimidir. Hegemonik erkeklik ise herhangi bir toplumdaki baskın erkeklik biçimidir. Fakat burada önemle belirtilmesi gereken nokta, toplumda birden fazla erkeklik halleri olduğu ve hegemonik erkekliğin bu biçimlerin içerisindeki kültürel olarak en baskını olduğudur. M. Butterfly' daki egemen beyaz, Batılı erkeklik hali olan hegemonik erkekliğe meydan okunmaktadır. Bu durum ise filmdeki diğer erkeklik halleri ile mücadele biçimini akla getirir. Bu noktada Foucault'un iktidarın ne/nasıl olduğu ve oluştuğu ile ilgili sorgulamasına kısaca değinmek gerekmektedir. Foucault iktidarın homojen bir egemenlik biçimi olmadığını ve dolaşımda olan bir ağ olduğunu ifade eder (2002: 42-43). M. Butterfly'da tıpkı Foucault'un (2002: 42- 47) tarif ettiği şekilde bir iktidar mücadelesi vardır. René 'nin Batılı beyaz erkeklik halinin Song'un üzerindeki tahakküm mekanizması ters düz olur ve aşağıdan yukarıya doğru bir egemenlik biçimi kendisini gösterir. René 'nin Song'u yönettiği ve egemenliğini Song'un Doğulu, egzotik kadın üzerinden kurguladığı hakimiyeti, Song'un Çinli bir casus erkek çıkması ve René 'nin Madam Butterfly performansıyla intihar etmesi iktidar ilişkilerini ters yüz eder.

Song 'un aslında bir Çinli casus olduğu gerçeğinin medyana çıktığı ve René'nin vatan haini olarakceza aldığı hapishane sahnesinin ardından, cezaeviarabası sahnesine geçilmektedir. 
Bu sahne René ve Song'un ayakkabılarına yakın çekim yaparak başlar. Her iki karakter de erkek elbiseleri taşımaktadır. Song kıyafetlerini çıkarınca karşısında güçlü ve Doğulu bir erkek gören René kahrolur. Gördüğünü reddeder ve Song'a “Sen benim Butterfly'ım değilsin. Bu kadar zamanı bir erkek için harcamış olmam çok komik" der. Mecazi anlamda Song'un çıkardığı kıyafetler aslında onun kimliğidir. Batılı kimliğini Song'un Doğulu kadınlığı üzerine kuran René, yıllardır bir yanılsama içerisinde olduğu gerçeğine katlanamaz. Bir anlamda kimliğini kaybeden René, kariyerinin en büyük gösterisi olacağını söylediği hapishanedeki Madam Butterfly performansinda intihar eder.

Tüm bu oryantalist bağlam ve erkeklik mücadelesi M. Butterfly' daki iktidarın ne olduğu sorusunu akıllara getirmektedir. M.Butterfly'da René'nin intihar ettiği hapishane Panopticon mimarisine göre inşa edilmiştir Bu bağlamda hapishane metaforik olarak okunabilir. Michel Foucault (1992) Hapishanenin Doğuşu adlı eserinde modern dünyadaki iktidar olgusunu ve iktidarın kullandığ1 yöntemleri anlatmaktadır. Disiplin toplumu olan modern devletler iktidarlarını Aydınlanma Çağının öncesinde olduğu gibi zorbalığa başvurmaktansa, bireylerin kendi kendileri üzerinde denetim kurmasını bir anlamda onların iktidarı içselleştirmesi yoluyla sağlarlar.

Aydınlanma Çağına kadar, Batı'da infazlar halkın görebileceği yerlerde gerçekleştirilmekteyken, iktidarın yapısı veya denetim biçimi modern toplumlarda bireylerin kendi kendileri üzerinde denetim kurması ile dönüşüm geçirmiştir. Bu bağlamda Foucault Panoptikon $^{11}$ metaforunu kullanır. Jeremy Bentham'ın 18. Yüzyılda önerdiği hapishane modelindeki mahkûmlar gibi, modern devlette yaşayan insanlar kendilerini sürekli gözetim altında hissedeceklerdir. Kendisini sürekli gözetim altında hisseden insanlar ister istemez hareketlerine çeki düzen verecek ve gözetlenmedikleri anlarda bile aykırı hareketlerde bulunmayacaklardır. Foucault (1992: 252) Panoptikon mimarisinin etkisinin tutukluda iktidarın otomatik işleyişini sürekli gözetleme ile ilişkisi ile ilişkilendirir. Böylece gözetim altında tutulmayla iktidar bir anlamda içselleştirilmektedir. Bu hapishanenin panoptikon mimarisine göre inşa edilmesini metaforik olarak okuduğumuzda René'nin mahkûm olduğu hapishane onun üzerinde baskı kuran topluma benzediğini ifade edebiliriz. Sürekli toplum baskısını üzerinde hisseden ve de buna göre davranan René aslında iktidarı içselleştirmiş kendisini sürekli kontrol altında tutmuş bir erkektir. Bu hapishane René'nin kimliği üzerinde baskı kuran ve onu kontrol eden bir mekanizmanın sembolü olarak görülebilir. René'nin bir geyşa elbisesi giyerek ve geyşa makyajı yapması onun erkek bedeninde başka bir kimlik taşıdığ olasılığına işaret eder. Diğer bir taraftan bu sahne René'nin beyaz, Batılı ve heteroseksüel erkek kimliği altında ezilmiş ve öfkesini bu şekilde yansıtması olarak da okunabilir. René'nin intiharı ise, hegemonik erkekliğe ${ }^{22}$ karşı gösterdiği bir direniş biçimidir.

1 Latince her şeyi gören anlamına gelen panoptes kelimesinden türemiştir. İngiliz hukukçu, sosyal reformist ütilitarizmin kurucusu kabul edilen Jeremy Bentham'ın hapishane modelinin ismidir. Bentham'a göre önemli olan bir suçun cezalandırılmasındansa suçun önlenmesidir. 18. Yüzyılın sonlarında hazırladığı hapishane modelinde cezaevi yuvarlaktır ve ortasında bir gözetleme kulesi vardır. Yuvarlak ceza evi parçalara bölünmüş ve hücreler hem içeriyi hem de dışarıyı görmektedirler. Gözetleme kulesinde ise bir gardiyan bulunur. Tek gardiyanın bakışıla tüm mahkûmlar gözetim altında tutulabilir. Gardiyan tüm mahkûmları rahatlıkla kontrol ederken, kendisini diğer mahkûmlar göremez.

2 Connell'e göre (2005) "hegemonik erkeklik" tek bir erkeklik biçiminden türemez. Bu bağlamda erkeklik sabit olamayan, akışkan ve her yerde tezahür eder. Gramsci' nin hegemonya kavramından yola çıkarak, Connell toplumlarda bu erkeklik hallerinden bir tanesinin kültürel olarak yüceltildiğini ifade eder. Bu çerçevede de hegemonik erkekliği bir cinsiyet pratiği olarak tanımlar ve bu pratiğin ne olduğu 


\section{Butterlfy'da Haz ve Özdeşleşme Sorunu}

Klasik anlatıyı belli bir zaman aralığında geçen, neden sonuç ilişkilerine sahip olaylar zinciri olarak tanımlayabiliriz. Burada anlatı bir durum ile başlar ve neden-sonuç ilişkisi ile devam eder. Bu anlatıda rastgele olaylar dizisi bir öykü oluşturmamaktadır. Olaylar dizisinin anlatı olabilmesi için neden sonuç ilişkisi olması gerekmektedir. Neden sonuç ilişkisini oluşturan ve ilerleten karakterlerdir. Karakterler anlatısal olarak işlev gösteren bazı özelliklere sahiptir. Filmde bu anlatının başkarakteri ile izleyici kendisini özleştirir, karakterin başarıları ile bir katarsis yaşar. Fakat $M$. Butterfly filmine baktığımızda René' nin hikayesini dinlediğimizi sanırken, Song' un hikayesi ile bir özdeşleşme kurmaktayız. Film esasen René'nin başkarakter olarak sunulması ile başlar ve Song'un başarısı ile biter.

Film ana akım sinemanın ideolojisi, kuralları ve kodlarıyla mücadele eden ve bunları yıkmaya çalışan filmler için kullanılan karşı sinema (Gürkan, 2015:36) ile uyumlu gözükmektedir. Peter Wollen (1972: 120-129) tarafından ortaya atılan karşı sinema kavramında belirttiği ana akım sinema ve karşı sinema arasındaki farklılıklardan bir tanesi Özdeşleşme Karşısında Yabancılaşma' dır. M. Butterfly filminde de özdeşleşme sorunu dikkat çekicidir.

Filmde, René'nin bir eylem planından ziyade, onun psikolojik bunalımlarına şahit olmaktayız. Böylece filmde başkarakter sorunu çıkmaktadır. Bu durum da özdeşleşme olgusunun ertelenmesine neden olmaktadır. Filmdeki bu durum akıllara izleyicinin bir antikahraman olan René ile mi yoksa kahraman olan Song ile mi özdeşleşeceği sorusunu akıllara getirir. Diğer bir yandan izleyicideki bilgi ile karakterlerin sahip olduğu bilgi arasındaki uçurum merak duygusunu tetiklemektedir (Oluk, 2013: 75). René'nin sahip olduğu bilgi ile izleyicinin sahip olduğu bilgi düzeyi arasındaki farklılık yine özdeşleşmede sorun yaratır. Bu bağlamda, René'nin intiharı ile izleyicinin özdeşlemesi askıda kalır. Diğer bir yandan René'nin Song'un kadın olduğunu zannetmesi ile yaşadığı haz ve izleyicinin Song'un erkek kimliğine sahip olduğunu bilmesi izleyicideki hetero hazzı engeller. İzleyici bu bağlamda queer ${ }^{33}$ bir haz yaşamaktadır. Başkarakterden farklı bir haz yaşaması da yine özdeşleşme sorunu ile ilişkilidir.

Filmde ana karakter ve öteki sorunu da dikkat çeker. Bu bağlamda yukarıdan aşağıya bir iktidar ilişkisi yoktur. Filmdeki öteki olma biçimi sürekli bir değiş-tokuş ile inşa edilir. Bu yüzden herhangi bir cinsel ve coğrafi kimliğin üstünlüğü söz konusu değildir. M. Butterfly filminde bu söylemi sadece René'nin ağzından dökülen cümlelerle duymuyoruz. Filmdeki çarpıcı bir cümle René' nin eşi Jeanne tarafından söylenmektedir "Ne zaman kaldırıma sümküren birisini görsem aklıma hep babamın söyledikleri geliyor, Doğu doğudur, Batı batıdır. Umarım hiç biraraya gelmezler." Filmin başında Doğu ve Batı birbirinden ayrı yerler olarak sunulmasına karşın bu fark zamanla kapanır ve neresinin doğu/batı olduğu sorgulanmaya başlar. Bu çerçevede birbirine bağlı ve birbirini oluşturan, sürekli birbiriyle etkileşim ve değişim içerisinde olarak tasvir edilmiştir. Jeanne' nin sorgulamasının bir felaketin göstergesi olup olmadığı ve Doğu ile Batı'nın bir araya gelmesi bu gerilimi azaltan bir şey olarak adlandırılması gerekliliği sorunu filmde her ne kadar cevaplanmasa da, neticede karakterlerin Doğu/Batı toplumlarına dair fantezi dünyasında bir yıkım meydana gelir. Bunun bir felaket olup olmadığı sorusunun

sorusunun cevabı ataerkil toplumun meşruiyetini neyin oluşturduğunun arkasında yatar (2005: 77).

3 Queer kelimesi, Türkçe "acayip", "şüpheli", "rahatsız", 'tuhaf', "iğreti", "kötü" gibi anlamlara gelirken, 1980 'lerin sonunda eşcinselleri aşağılamak için kullanılmıştır. Kavram bir zamanlar eşcinsel bireyleri aşağılamak ve yalnızlaştırmak için kullanılırken, 90'lı yıllarla beraber politik bir bağlam kazanarak, cinsel ayrımcılığa karşı duranlar tarafından bir tepki olarak sahiplenilmiştir. Stratejik ve politik olarak kavramın barındırdığı olumsuz anlamların içerisinin boşaltılması amaçlanmıştır. 
cevabı ise izleyiciye bırakılmaktadır. Said'in (2003: 14) dediği gibi "Bu iki coğrafi varlık birbirini destekler, bir ölçüde birbirini yansıtır." Bu açıdan bakıldığında izleyici kendisini ne doğuya ne de batıya ait hissetmekte ve özdeşleştirmektedir. Bu çerçevede izleyicinin konumu yalnızca cinsiyet rolleri açısından değil, aynı zamanda hangi coğrafyaya ait olacağı hususunda da askıda kalır.

\section{Sonuç ve Değerlendirme}

David Henry Hwang tarafından bir tiyatro eseri olarak yazılan,1993 yılında David Cronenenberg tarafından sinemaya uyarlanan M. Butterfly isimli film, Giacomo Puccini'nin üç perdelik Madam Butterfly operasının basmakalıp karakterlerini ters yüz eden bir anlatıma sahiptir. M. Butterfly konu olarak Pucci'nin eseriyle benzerlikler taşısa da, anlatım olarak Pucci'nin eserinden ayrılır. Pucci'nin eseri kadınlık ve erkeklik rollerini düz bir şekilde anlatmaktadır. Bu anlatımda kadına ve erkeğe dayatılan roller vardır ve kadınlığın/erkekliğin biyolojik farklılıklar neticesinde bir üstünlük aracı olarak sunulur. Madam Butterfly' daki anlatım tam da bu noktadan şekillenmektedir. Batılı, beyaz bir erkeğin, Doğulu egzotik, pasif bir kadın üzerindeki tahakkümünü ortaya koyan bu söylem, Cronenberg' in filmi M. Butterfly'da adeta yapısöküme uğratılır. Filmin ismi olan M.Buttefly'daki M.vurgusu kadınlık ve erkekliğe dair sorgulamanın bir göstergesidir. Kimin mösyö, kimin madam olduğu yalnızca karşılıklı kimlik değiş-tokuşlarıyla belirlenebilir ve bu süreç yalnızca biyolojik bir aktarımdan ibaret değildir. 1960'larda geçen, Fransız diplomat René Gallimard ve Çinli opera sanatçısının aşkını konu alan film kadın ve erkek olmanın toplumsal olarak belirlendiğini ve performe edilen roller olduğunu ortaya koymaktadır. Film boyunca kadın olarak bildiğimiz Song ile erkek olarak gösterilen René'nin rolleri birbiriyle değiştirilirler. Filmin sonunda René'yi Doğulu bir kadın, Song'u ise Batılı bir erkek olarak görmekteyiz. Bu bağlamda film, kadın ve erkek olmanın toplumsal olarak inşa edilen ve performansa dayalı olduğunu gözler önüne sererken, bir yandan da bu rolleri sorgulamamıza neden olmaktadır. Bu bağlamda film kadınlık ve erkeklik rollerini alt üst eden bir yerde durmaktadır. Bunun yanı sıra film, Doğulu ve Batılı olmayı da yapısökümcü bir söylemle ortaya koyar. Fakat her ne kadar film geleneksel rollere medyan okuyan bir atmosfere sahip olsa da, filmin sonunda geleneksel toplumsal cinsiyet rollerinin yeniden inşa edildiği ifade edilebilir. René 'nin Batılı ve beyaz erkeklik kimliğinin krizinin sonucu olarak intiharı ise, toplumsal rollerden çıkışın imkansızlığını vurgular. Ayrıca, filmin sonunda değişen Doğulu/Batılı ve kadın/erkek rolleri de kadınlık ve erkeklik rollerine dair çizilen ilk tablo, filmin sonunda yeniden inşa edilir. Fakat bir diğer yandan René'nin intiharı oldukça varoluşçu bir eylemdir. Burada kendisine yeni bir yol seçmiş ve geleneksel rollerden sıyrılma biçimini bu şekilde performe etmiştir. Bu bağlamda intiharın filmde askıda kalan bir diğer eylem olarak yorumlanması daha doğru olacaktır.

\section{Kaynakça}

Akay, A. (1999). Yapibozma ve Plastik Sanatlar. Toplumbilim Jacques Derrida Özel Sayısı, Sayı, 10, 13-23.

Barthes, R. (1977). Image- Music- Text. (S. Heath, Çev.). New York: Hill \&Wang.

Brunette, P. (1986). Toward A Deconstructive Theory of Film. Studies in the Literacy Imagination, 19 (1), 55-71. 
Burcu, E. (1998). Evrimci Teorinin Sosyolojik Düşünce Üzerindeki Etkileri ve Sosyobiyoloji. Hacettepe Üniversitesi Edebiyat Fakültesi Dergisi ,15 (2), 175-186.

Butler,J. (1988). Performative ActsandGenderConstitution: AnEssay in Phenomenology And Feminist Theory. Theatre Journal, 40, (4), 519-531.

Connell, R.,W., (2005). Masculinities.Los Angeles: University California Press.

Cronenberg, D. (Yönetmen). (1993). M. Butterfly. USA: Warner Bros.

Derrida, J. (1999a). Japon Bir Dosta Mektup. (M. Atıcı ve M. Omay Çev.) Toplumbilim Jacques Derrida Özel Sayısı, 10, 185-188.

Derrida, J. (1999b), İnsan Bilimlerinin Söyleminde Yapı, Gösterge ve Oyun. (Ö. Gözel ,Çev.) Toplumbilim Jacques Derrida Özel Sayısı, 10, 65-173.

Derrida, J. (2010). Gramatoloji. (İ. Birkan Çev.). Ankara: Bilge Su.

Esplen, E. ve Jolly, S. (2006). Gender and Sex a Sample of Definitions. U.K: Bridge.

Fausto-S.A. (2000). Sexing the Body. New York: Basic Books.

Foucault, M. (1992). Hapishanenin Doğuşu. (M. A. Kılıçbay, Çev.). Ankara: İmge.

Foucault, M. (2002). Toplumu Savunmak Gerekir. (Ş. Varaktaş, Çev.). İstanbul: Yapikredi.

Gabriella Martinelli (Yapımc1) \& Cronenberg, D. (Yönetmen). (1993). M. Butterfly. [Sinema Filmi]. ABD: Warner Bros.

Goffman, E. (2014). Günlük Yaşamda Benliğin Sunumu. (B. Cezar, Çev.). İstanbul: Metis.

Gürkan, H. (2015). Karşı Sinema. İstanbul: Es.

Hall, S. (1997). Old and New Identities, Old and New Ethnicities . A.,D. King (Ed.), Culture, Globalization And The World-System Contemporary Conditions for The Representation of Identity içinde (40-68). New York: University Minnesota Press.

Hoffman, H. (1997). Stereotypes As Reinforced Structure in M. Butterfly. Undergraduate Review, 10 (1), 53-60.

Hwang, D.H. (1992). M. Butterfly. (A.Taygun, Çev.). İstanbul: Can.

Metz, C. (1974). Language and Cinema. (D. Jean, Çev.). Lahey: Mouton.

Oluk, A. (2013). Klasik Anlatı Sineması. İstanbul: Hayalperest.

Puccini, G. (1903). Madam Butterfly. [Opera].

Rajyavardhan, K. ve Sharma, S. (2017). Deconstruction as A Method of Film Criticism. The Researcher- International Journal of Management Humanities and Social Sciences. 2 (2), 21-27.

SSaid, W. E. (2003). Şarkiyatçılık. (B. Ülner,Çev.) Ankara: İmge.

Sarup, M. (1997). Post-Yapısalcılık ve Postmodernizm. (B. Güçlü, Çev.) Ankara: Bilim ve Sanat. 
Sayer, A. (1997). Essentialism, Social Constructionism And Beyond. Sociological Review 45 (3), 453-487.

Sim, S. (2000). Derrida ve Tarihin Sonu. Kaan H. Ökten (Çev.). İstanbul: Everest.

Stam, R. (2014). Sinema Teorsine Giriş. (S. Salman ve Ç. Asatekin, Çev.). İstanbul: Ayrıntı.

Uluç, G. ve Soydan, M. (2007). Said, Oryantalizm, Resim ve Sinemanın Kesişme Noktasında Harem Suare. Türk Dünyası Sosyal Bilgiler Dergisi. 42, 35-53.

Wollen, P. (1986). Godard And Counter Cinema: Vent D'est, Narrative. P. Rosen (Ed.), Apparatus, İdeology: A Film Theory Reader içinde (s.120 - 129). New York: Colombia University Press. 